Journal of Immunogenetics (1975) 2, 9-25.

\title{
Ia ANTIGENS ON MURINE LYMPHOID CELLS: DISTRIBUTION, SURFACE MOVEMENT AND PARTIAL CHARACTERIZATION*
}

\author{
J. W. Goding, G. J. V. Nossal, D. C. Shreffler $\dagger$ and \\ J. J. MarChalonis \\ The Walter and Eliza Hall Institute of Medical Research, Post Office, Royal Melbourne \\ Hospital, Parkville 3050, Victoria, Australia and $\dagger$ the Department of Human Genetics, \\ University of Michigan, Ann Arbor, Michigan
}

(Received 16 January 1975)

\begin{abstract}
SUMMARY
Antisera directed against the I (immune response gene) segment of the murine major histocompatibility complex were prepared, and the distribution of lymphoid cells binding the antisera studied by radioautography. A clear bimodal distribution of grain counts was observed in lymph node and spleen. Bone marrow lymphocytes showed heavy but heterogeneous labelling, while thymocytes were lightly but definitely labelled. Approximately $30 \%$ of lymph node cells and $60 \%$ of spleen cells were heavily labelled. The heavily labelled cells were shown to be B cells. Ia antigens are present on plaque forming cells, but probably in smaller amounts than on resting B cells. One plasma cell tumour was studied, and was found to possess little or no Ia antigen.

There was no demonstrable labelling of thoracic duct lymphocytes from preparations of $T$ cells activated to histocompatibility antigens. However, several $\mathrm{T}$ cell lymphomas probably possess Ia antigens, since they were rejected when transplanted into mice differing at the I region. Overall, the data indicate that Ia antigens are expressed on at least some $T$ cells.

The Ia antigens were shown to move independently of surface immunoglobulin on B cells, demonstrating the non-identity of these molecules. Pretreatment of $B$ cells with anti-immunoglobulin did not inhibit binding of anti-Ia sera. The Ia antigens could be capped by a sandwich technique in $75 \%$ of labelled cells.

The Ia antigens were specifically precipitated from lysates of surface radioiodinated spleen cells, and the products analysed by polyacrylamide gel electrophoresis in the presence of sodium dodecyl sulphate. A single specific peak of radioactivity corresponding to a molecular weight of approximately 30,000 was

* This is publication No. 1982 from the Walter and Eliza Hall Institute.

Correspondence: Dr J. W. Goding, Walter and Eliza Hall Institute of Medical Research, Post Office, Royal Melbourne Hospital, Parkville 3050, Victoria, Australia.
\end{abstract}


found. The significance of these results in relation to immune response genes, receptors for antigen on $T$ cells, and receptors for the $F c$ portion of IgG on B cells, is discussed.

\section{INTRODUCTION}

In many species, the immune response to certain antigens is under the control of specific 'immune response' ( $I r)$ genes which are closely linked to the major histocompatibility complex (Benacerraf \& McDevitt, 1972; Shreffler \& David, 1974). These genes apparently show dominant inheritance and control specific immune responsiveness at the $T$ cell level, although their precise mode of action has not been determined. It has been proposed (Benacerraf \& McDevitt, 1972) that these genes represent structural genes for a nonimmunoglobulin receptor for antigen on T cells. However, evidence for such an hypothesis is indirect, and other models for Ir gene function have been proposed (Marchalonis et al., 1974; Katz \& Benacerraf, 1974).

Recently, congenic strains of mice have become available which differ at the H-2I chromosomal segment, but are identical at the H-2K and H-2D loci (Shreffler \& David, 1974). When mice of one strain are immunized against lymphoid cells of the partner, antibodies cytotoxic to lymphocytes are produced in high titre (David et al., 1973; Hauptfeld et al., 1973). The antigens detected by these antisera are independent of the H-2K and H-2D antigens, and have been termed Ia (I region associated) antigens (Shreffler et al., 1974).

In view of the apparent functional expression of $\mathrm{H}-2$ linked $I r$ genes in $\mathrm{T}$ cells, it was expected that Ia antigens would also be expressed in T cells. However, evidence has been presented for exclusive B cell localization of Ia antigens (Hammerling et al., 1974; Sachs \& Cone, 1973), exclusive $T$ cell localization (Gotze et al., 1973) and expression on both cell types (Frelinger et al., 1974b).

As a preliminary approach to the question of the relationship between Ia antigens and products of the H-2 linked immune response genes, we have set out to determine whether anti-Ia antisera bind predominantly to $T$ cells, $B$ cells or both, using radioautography and a variety of lymphoid cell populations. In populations where a mixture of $\mathrm{T}$ and $\mathrm{B}$ cells were present, a bimodal distribution of grain counts was observed, and the heavily labelled cells were shown to be B cells. Weaker, but definitely significant binding was also observed in thymocytes. The antigens were shown to be non-immunoglobulin in nature, as they did not co-cap with immunoglobulin on B cells. They have an estimated subunit molecular weight of approximately 30,000 .

\section{MATERIALS AND METHODS}

Mice

A.TH and A.TL mice were progeny of breeding pairs obtained from the Department of Human Genetics, University of Michigan, and were used at an age of 6-8 weeks. Their H-2 genotypes are:

\begin{tabular}{lllll}
\hline Strain & K & I & S & D \\
\hline A.TH & s & s & s & d \\
A.TL & s & k & k & d \\
\hline
\end{tabular}


$\mathrm{CBA} / \mathrm{H}$ mice $\left(\mathrm{H}-2^{\mathrm{k}}\right)$ and $\mathrm{CBA} \times \mathrm{C} 57 \mathrm{Bl} \mathrm{F}_{1}$ mice $\left(\mathrm{H}-2^{\mathrm{kb}}\right)$ were obtained from colonies maintained at the Walter and Eliza Hall Institute by Dr M. C. Holmes.

Congenitally athymic ('nude') mice in their fourth generation of backcrossing to CBA mice, and possessing the $\mathrm{H}-2^{\mathrm{k}}$ histocompatibility complex, were provided by $\mathrm{Dr} \mathrm{M}$. C. Holmes.

\section{Antisera}

A.TH anti A.TL serum was prepared as described by David et al. (1973). Briefly, A.TH mice were injected four times intraperitoneally with a mixture of $2 \times 10^{6} \mathrm{~A}$.TL thymocytes and $6 \times 10^{5}$ A.TL lymph node cells at weekly intervals, followed by monthly booster injections until a high cytotoxic titre was obtained. The serum was partially purified by starch block electrophoresis (Kunkel, 1954). The gamma globulin fraction was concentrated to $1 \mathrm{mg} / \mathrm{ml}$ by pressure dialysis.

A strong polyvalent rabbit anti-mouse $\operatorname{IgM}$ serum was prepared as previously described (Nossal et al., 1972).

Anti Thy 1.2 (previously anti $\theta$ ) serum was prepared by the method of Reif \& Allen (1963), and was tested for cytotoxicity against CBA thymocytes and CBA plaque forming cells. Any batches showing B cell reactivity were extensively absorbed with 'nude' mouse spleen cells. In order to eliminate Thy 1.2 positive cells, $10-30 \times 10^{6}$ viable cells were suspended in $1 \mathrm{ml}$ antiserum and incubated at $37^{\circ} \mathrm{C}$ for $30 \mathrm{~min}$. They were then washed, and resuspended in $1.5 \mathrm{ml}$ agarose absorbed guinea-pig complement (final dilution 1:6). After incubation at $37^{\circ} \mathrm{C}$ for $30 \mathrm{~min}$, the cells were washed twice.

\section{Cell suspensions}

These were prepared essentially as described by Nossal et al. (1972). Care was taken to avoid removing parathymic lymph node with thymus tissue. Lymph node specimens included nodes from the inguinal, axillary and mesenteric groups. In each case, cells from three to four mice were pooled. Dead cells were removed by the method of von Boehmer \& Shortman (1973). This method was shown by the authors to have a very high recovery of live cells, and no selective loss of $\mathrm{T}$ cells, $\mathrm{B}$ cells or macrophages. Typical viabilities as assessed by eosin exclusion were $93-98 \%$.

\section{Radio-iodinations}

Rabbit anti mouse IgM was radio-iodinated with ${ }^{125} \mathrm{I}$ by the chloramine-T method (Greenwood et al., 1963) to a specific activity of $12 \mu \mathrm{Ci} / \mu \mathrm{g}$, and used as a concentration of $0.2 \mu \mathrm{g} / \mathrm{ml}$.

In order to minimize denaturation of mouse antibodies, anti-Ia antisera were trace labelled with ${ }^{125}$ I by the lactoperoxidase method (Marchalonis, 1969). Specific activity was approximately $3 \mu \mathrm{Ci} / \mu \mathrm{g}$. Unbound iodide was removed by gel filtration. Iodinated anti-Ia antisera were absorbed for autoantibodies by mixing with an equal volume of thymus and spleen cells from A.TH mice at $4^{\circ} \mathrm{C}$ for $1 \mathrm{hr}$. Cells were then removed by centrifugation at $400 \mathrm{~g}$ for $5 \mathrm{~min}$. The antisera were then centrifuged at $10,000 \mathrm{~g}$ for $1 \mathrm{hr}$ to remove particulate matter. Radio-iodinated antisera were stored at $4^{\circ} \mathrm{C}$ and used within 4 days of preparation.

\section{Radioautography}

This was performed as previously described (Nossal et al., 1972). $5 \times 10^{6}$ cells were held at $4^{\circ} \mathrm{C}$ for $30 \mathrm{~min}$ with radiolabelled antiserum and then washed through fetal calf serum 
gradients and smeared onto gelatin coated glass slides. The slides were then dipped in NTB-2 photographic emulsion, exposed, developed, and stained with Giemsa. Routinely, anti-Ia serum was used at a concentration of $25 \mu \mathrm{g} / \mathrm{ml}$, and slides were exposed for 3 days. Between 300 and 1000 cells were counted per slide. In some cases, grain counts were performed. In others, cells with more than seven grains were scored as labelled. Only morphologically intact cells resembling lymphocytes were scored. Damaged cells and areas of high background were not scored.

Ia antigens on plaque forming cells

CBA $\left(\mathrm{H}-2^{\mathrm{k}}\right)$ mice were immunized with 4-hydroxy-3-iodo-5-nitrophenyl acetic acid conjugated to polymerized flagellin (NIP-POL) as previously described (Schlegel, 1974). After 3 or 7 days, mice were killed, their spleens removed and assayed for haemolytic plaque forming cells. Cell suspensions were diluted to give 50-200 plaques per chamber. Enough cells to fill six chambers (typically $10^{7}$ ) were held with $200 \mu$ l undiluted A.TH and A.TL antiserum for $30 \mathrm{~min}$ at $4^{\circ} \mathrm{C}$, washed, and incubated for a further $30 \mathrm{~min}$ at $37^{\circ} \mathrm{C}$ with selected nontoxic rabbit complement diluted 1:12. They were then tested for anti-NIP plaque forming cells, using sheep red cells coated with NIP conjugated (Fab) ${ }_{2}$ fragments of rabbit anti-sheep IgG. Controls included complement only, A.TL anti A.TH serum (negative controls) and Balb/c anti CBA serum (positive control).

\section{C1.18 tumour}

This plasma cell tumour (also known as X5563) arose in a C3H (H-2 $)$ mouse (Potter $e$ t al., 1957), and is maintained in tissue culture at the Walter and Eliza Hall Institute by Dr A. W. Harris.

\section{Cell electrophoresis}

This was performed according to von Boehmer (1974). This method separates cells on the basis of charge, $T$ cells being more negatively charged than $B$ cells, and, therefore, migrating further towards the anode. Spleen cells from A.TL mice were processed, and each fraction divided into two equal parts. One was exposed to ${ }^{125}$ I A.TH anti A.TL serum, and the other to ${ }^{125} \mathrm{I}$ anti IgM serum. The cells were then processed for radioautography.

\section{Activated T cells}

$\mathrm{CBA} \times \mathrm{C} 7 \mathrm{~B} 1 \mathrm{~F}_{1}$ mice were irradiated with $850 \mathrm{rad}$, and then injected intravenously with $100 \times 10^{6} \mathrm{CBA}$ thymocytes. Four days later, the thoracic ducts were cannulated, or the mice were killed and the spleens removed. The thoracic duct lymph from such mice contains less than $0.5 \%$ B cells (Basten et al., 1972).

\section{Adult thymectomized and reconstituted mice}

CBA mice were thymectomized at 6-8 weeks, and irradiated (850 rad) 2-4 weeks later. They were then injected intravenously with $5 \times 10^{6}$ syngeneic fetal liver cells, and kept 1-2 months before use. Any animal showing thymic remnants at autopsy was discarded.

\section{Capping of surface immunoglobulin}

Fluorescein conjugated purified sheep antibody to rabbit IgG was a generous gift of Dr P. W. Kincade. Sheep antibodies to rabbit IgG (DEAE fraction $0.01 \mathrm{M}$ tris- $\mathrm{HCl} \mathrm{pH} \mathrm{8.0}$ -DE 52 cellulose) were passed over a sepharose immunoadsorbent of normal mouse 
globulin to remove cross-reactive antibodies. Antibodies were eluted from an immunoadsorbent of the rabbit IgG and fluorescein labelled (Kincade \& Cooper, 1971). The F/P ratio was 2.8 and the antibodies were used at $0.5 \mathrm{mg} / \mathrm{ml}$. Fluorescent cells were detected using a Leitz Orthoplan microscope, with type 250 lamp housing, $200 \mathrm{~W}$ ultra high pressure mercury lamp, BG 38 red suppression filter, $2 \times$ KP490 exciting filter, TK 510 dichroic beam splitting mirror and $\mathrm{K} 515$ suppressor filter.

Ten million A.TL spleen cells were held at $4^{\circ} \mathrm{C}$ for 30 min with a $1: 30$ dilution of rabbit anti mouse IgM serum. They were then washed, and heid for $15 \mathrm{~min}$ with fluorescein conjugated sheep anti rabbit IgG, washed again, and warmed to $37^{\circ} \mathrm{C}$ for $10 \mathrm{~min}$. An aliquot of cells was removed and examined for capping by fluorescence microscopy. The remaining cells were cooled to $4^{\circ} \mathrm{C}$, held with ${ }^{125} \mathrm{I}$ anti Ia serum or normal A.TH serum, and processed for radioautography as previously.

\section{Characterization of Ia antigens}

A.TL spleen cells were treated with tris buffered ammonium chloride to remove red cells (Boyle, 1968), and then dead cells were removed as previously. Fifty million cells were surface iodinated with ${ }^{125} \mathrm{I}$ by the lactoperoxidase technique (Marchalonis et al., 1971) using a total of $2.5 \mathrm{mCi}^{125} \mathrm{~T}$-iodide. The cells were washed once, and lysed with $3.5 \mathrm{ml} 1 \%$ Nonidet P-40 (British Drug Houses, Melbourne) in phosphate buffered saline(PBS) pH 7.4 for $30 \mathrm{~min}$ at room temperature. The lysate was then centrifuged at $1000 \mathrm{~g}$ to remove debris, and dialysed overnight at $4^{\circ} \mathrm{C}$ against PBS. It was then centrifuged at $10,000 \mathrm{~g}$ for $30 \mathrm{~min}$. The supernatant was passed over a small column of rabbit anti mouse IgG serum coupled to Sepharose 4B (immunoglobulin binding capacity $400 \mu \mathrm{g} / \mathrm{ml}$ gel). The effluent was then held at $37^{\circ} \mathrm{C}$ for $1 \mathrm{hr}$ with $500 \mu \mathrm{l}$ of $0.1 \mathrm{mg} / \mathrm{ml}$ gamma globulin fraction of A.TH anti A.TL serum or normal A.TH serum. Mouse immunoglobulin was then quantitatively precipitated with rabbit anti mouse immunoglobulin. The precipitates were washed four times, and then boiled in a buffer solution containing $5 \%$ mercaptoethanol and $3 \%$ sodium dodecyl sulphate, and analysed by discontinuous polyacrylamide gel electrophoresis as described by Laemmli \& Favre (1973). The total concentration of polyacrylamide was $10 \%$, and the concentration of bis acrylamide was $0.25 \%$. Gels were sliced and counted in a Packard gamma counter. Calibration of molecular weights was performed by running parallel gel electrophoresis of proteins of known molecular weight.

\section{RESULTS}

\section{Establishment of conditions}

A number of preliminary experiments were performed to establish suitable conditions for radioautography. It was found that a suitable degree of labelling was achieved by a concentration of ${ }^{125} \mathrm{I}$ A.TH anti A.TL serum of $25 \mu \mathrm{g} / \mathrm{ml}$, and an exposure time of 3 days. Under these conditions, it was clear that a subpopulation of lymphocytes in spleen and lymph node were very heavily labelled, while the remainder were not significantly labelled above background.

A very clear visual distinction between heavily labelled and lightly labelled cells was observed over a concentration range of $15-50 \mu \mathrm{g} / \mathrm{ml}$ of antiserum, and exposure times of 2-10 days. An indication of the distribution of grains is shown in Fig. 1 (3 day exposure, $25 \mu \mathrm{g} / \mathrm{ml}$ ). It should be noted that visually the distinction between lightly labelled and 


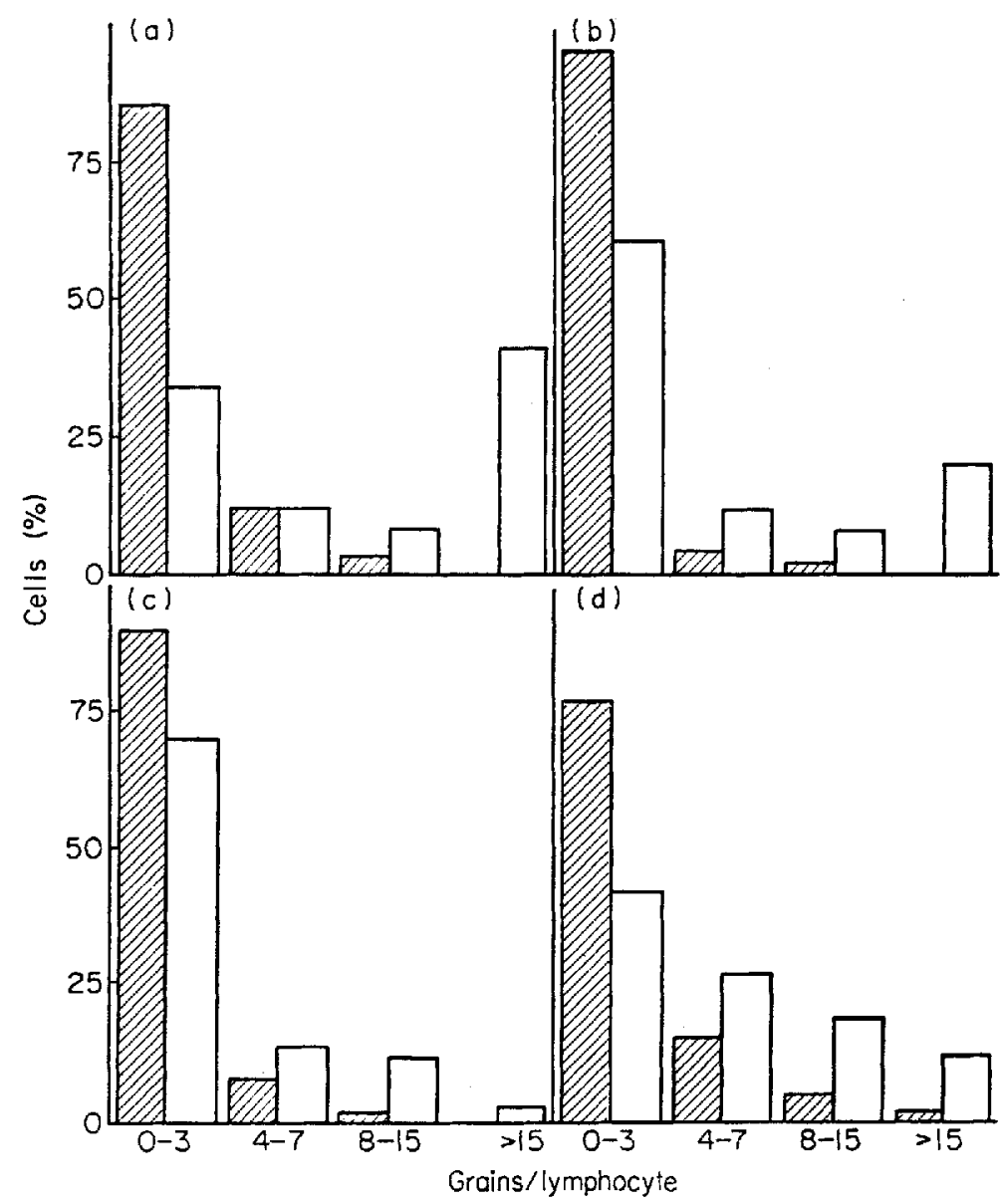

FIG. 1. Grain counts after treatment of A.TH (shaded) or A.TL (clear) cells with $25 \mu \mathrm{g} / \mathrm{ml}$ ${ }^{125}$ I A.TH anti A.TL serum. Exposure time was 3 days. (a) Spleen; (b) lymph node; (c) thymus; (d) bone marrow.

heavily labelled cells was much more striking than would appear from the histograms, because most of the cells in the category of greater than fifteen grains were so heavily labelled that accurate grain counts were impossible (50-100 grains/cell). Except where noted, all subsequent experiments were performed using an antiserum concentration of $25 \mu \mathrm{g} / \mathrm{ml}$ and an exposure time of 3 days.

Control smears (binding of A.TH anti A.TL serum to A.TH cells) showed in general a very low degree of labelling. However, in early experiments significant but light labelling was noted in A.TH thymocytes, but not A.TH lymph node cells. This labelling was apparently due to autoantibodies directed against thymocytes, as it could be completely abolished by absorption with A.TH thymocytes. In subsequent experiments, antisera were routinely absorbed for autoantibodies. After such absorptions, control smears were very satisfactory in thymus and lymph node, although some persistent non-specific labelling remained in spleen and bone marrow (Fig. 1). 
While there was a striking bimodal distribution of grains in lymph node and spleen, the distribution of grains was very heterogeneous in both thymus and bone marrow, with no indication of discrete binding subpopulations in these organs. It was consistently noted that there was a higher percentage of heavily labelled cells in spleen than in lymph node. After absorption of autoantibodies there was persistent specific, though very light, labelling in thymus. In a second experiment (Table 1), A.TH anti A.TL serum was absorbed sequentially with two aliquots of A.TH thymocytes, and longer exposure times used. Highly significant labelling of A.TL thymocytes was observed.

TABLE 1. Grain counts after 10-day exposure of A.TH and A.TL thymocytes to $25 \mu \mathrm{g} / \mathrm{ml}^{125}{ }^{12}$ A.TH anti A.TL serum. Paired differences were tested for significance by Student's $t$-test; $P<0.001$

\begin{tabular}{ccc}
\hline Serum & Cells & Grains/cell \\
\hline${ }^{125}$ I A.TH anti A.TL & A.TH thymocytes & $1.02 \pm 0.18$ \\
${ }^{125}$ I A.TH anti A.TL & A.TL thymocytes & $6.89 \pm 0.93$ \\
\hline
\end{tabular}

Use of non-congenic mice as targets for A.TH anti A.TL serum

Because of a shortage of the congenic mice (they appear to breed very poorly), and in order to allow experiments involving non-congenic mice, A.TH anti A.TL serum was tested for binding to cells from CBA mice. These mice possess the $\mathrm{H}-2^{k}$ major histocompatibility complex, and hence the $\mathrm{k}$ haplotype in the I region. Provided that there are only significant antibodies against the I region antigens in A.TH anti A.TL serum, CBA mice should be a valid target for such antisera. Experiments of this type were highly satisfactory. The bimodal distribution of labelling was well preserved, and there was no evidence of significant natural antibodies to CBA antigens in unimmunized A.TH serum.

\section{Nature of the heavily labelled cells}

A variety of subsequent experiments was performed to determine the nature of the heavily labelled cells. The consistent finding of more heavily labelled cells in spleen than in lymph node, and the considerable number of heavily labelled cells in bone marrow but not in thymus, strongly suggested that the heavily labelled cells were B lymphocytes. When a population of A.TL lymph node cells were treated with anti Thy 1.2 serum and complement, an increase in the fraction of heavily labelled cells was consistently observed. In one experiment, for example, the percentage of cells with more than seven grains increased from $31 \%$ to $98 \%$, while the percentage of cells bearing surface immunoglobulin increased from $29 \%$ to $96 \%$.

When adult CBA thymectomized, irradiated and fetal liver reconstituted mice were used as targets, there was a similar increase (Table 2), which was more pronounced in lymph node than in spleen. Similarly, when A.TH anti A.TL serum was tested for binding to cells from CBA nude mice, the great majority of spleen cells showed heavy labelling (Table 3 ). Approximately $75 \%$ of spleen cells from these mice have high density surface immunoglobulin (Osmond \& Nossal, 1974).

A.TL spleen cells were fractionated by cell electrophoresis, and each fraction tested for binding of A.TH anti A.TL serum or anti IgM serum. The results are shown in Fig. 2. The 
TABLE 2. Percentage cells binding A.TH anti A.TL serum in normal CBA mice and CBA mice depleted of $T$ cells. The concentration of antiserum was $25 \mu \mathrm{g} / \mathrm{ml}$, and the exposure time was 3 days. Cells with more than seven grains were scored as positive

\begin{tabular}{lcc}
\hline \multirow{2}{*}{ Organ } & \multicolumn{2}{c}{ Labelled cells (\%) } \\
\cline { 2 - 3 } & Normal CBA & T cell depleted \\
\hline Spleen & 55 & 78 \\
Lymph node & 25 & 89 \\
\hline
\end{tabular}

TABLE 3. Binding of ${ }^{125}$ I A.TH anti A.TL serum to spleen cells of congenitally athymic ('nude') mice bearing the $\mathrm{H}-2^{k}$ chromosome. Conditions as for Fig. 3. Mean \pm standard error of three experiments

\begin{tabular}{lc}
\hline \multicolumn{1}{c}{ Serum } & Labelled cells (\%) \\
\hline A.TH anti A.TL & $78 \cdot 7 \pm 5 \cdot 2$ \\
Normal A.TH & $1 \cdot 0 \pm 0 \cdot 3$ \\
\hline
\end{tabular}

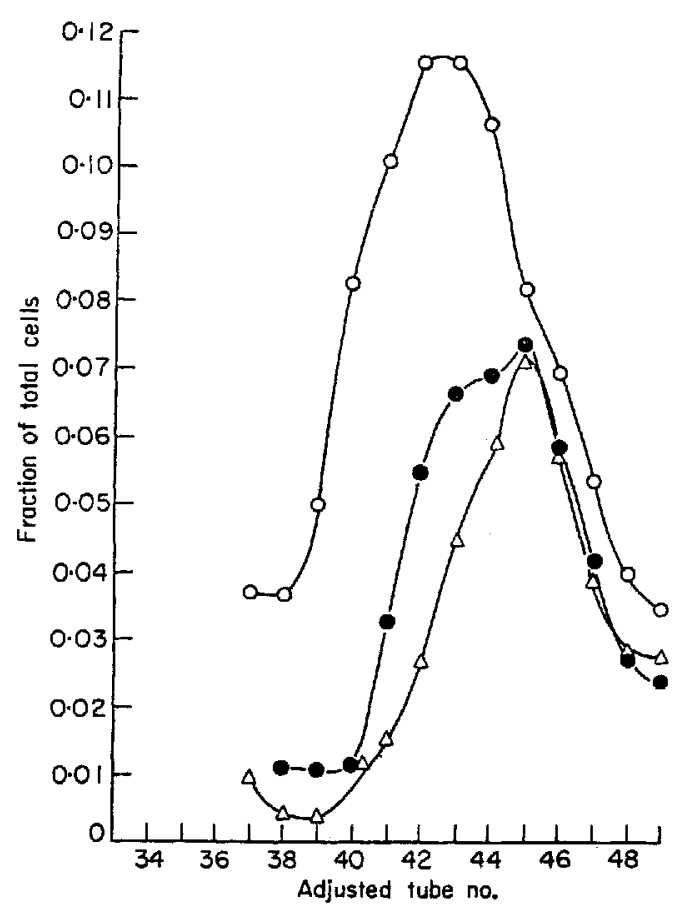

FIG. 2. Analysis of relative electrophoretic mobility of cells bearing Ia determinants and cells bearing high density surface immunoglobulin. $O$, Total cells (Coulter counter); $\Delta$, Igt; $\bullet$, Ia + (A.TH anti A.TL) 
$\mathrm{Ig}+$ and Ia+ peaks overlap almost completely, although there was a slight excess of ' $\mathrm{Ia}+, \mathrm{Ig}-$ ' cells on the left of the main binding peak. These cells could represent either labelled $T$ cells or 'null' (Thy 1.2 negative, $\mathrm{Ig}-$ ) cells. It is of interest that it is in precisely this position that the null cells are found (von Boehmer, 1974), and that by adding the 'null' and 'Ig+' figures, a curve very similar to the 'Ia+' curve can be constructed.

On the other hand, cells from populations strongly enriched for $\mathrm{T}$ cells showed greatly reduced labelling. The binding of radio-iodinated A.TH anti A.TL serum to CBA thymocytes activated to $\mathrm{C} 57 \mathrm{Bl}$ histocompatibility antigens is shown in Table 4 . There was absolutely no detectable labelling of thoracic duct lymphocytes (T.TDL's) from these animals. A very slight degree of labelling in spleen cells (splenic ATC's) was noted.

\begin{tabular}{|c|c|c|c|c|}
\hline \multirow[b]{2}{*}{ Serum } & \multirow[b]{2}{*}{ Cells } & \multicolumn{3}{|c|}{ Grains/cell } \\
\hline & & $0-3$ & $4-7$ & $>7$ \\
\hline A.TH anti A.TL & Spleen & 77 & 13 & 10 \\
\hline Normal A.TH & Spleen & 83 & 14 & 3 \\
\hline A.TH anti A.TL & Thoracic duct & 93 & 7 & 0 \\
\hline Normal A.TH & Thoracic duct & 97 & 3 & 0 \\
\hline
\end{tabular}

\section{Ia antigens on plaque forming cells}

Initial experiments to test for the presence of Ia antigens on plaque forming cells (PFC) gave negative results. When $50 \times 10^{6}$ immune CBA spleen cells were incubated with $200 \mu \mathrm{l} 1: 10 \mathrm{~A}$.TH anti A.TL serum, washed, and treated with complement, a reduction of only $10-15 \%$ in PFC was noted. However, when the cell numbers were reduced to $10^{7}$, and undiluted anti Ia serum was used, a very marked reduction in PFC was observed (Table 5).

TABLE 5. Effect of anti Ia serum and complement on CBA plaque forming cells. Results are expressed as a percentage of untreated cells (mean \pm standard error; three replicates per group)

\begin{tabular}{lcc}
\hline & \multicolumn{2}{c}{$\begin{array}{c}\text { Plaque forming cells after } \\
\text { treatment }(\%)\end{array}$} \\
\cline { 2 - 3 } \multicolumn{1}{c}{ Treatment } & Direct & Indirect \\
\hline Complement alone & 100 & 100 \\
A.TL anti A.TH + C' & $90 \pm 8.5$ & $88 \pm 4.8$ \\
A.TH anti A.TL + C' & $6 \pm 0.6$ & $6 \pm 0.9$ \\
Balbic anti CBA $+C^{\prime}$ & $3 \pm 0.7$ & $1 \pm 0.9$ \\
\hline
\end{tabular}


This reduction was specific, since A.TL anti A.TH (anti Is) serum caused no significant reduction of plaque numbers.

Occasional cells having the morphological characteristics of plasma cells in spleen smears appeared to be very lightly labelled. An $\mathrm{H}-2^{k}$ plasma cell tumour $\mathrm{Cl} .18$ derived from $\mathrm{C} 3 \mathrm{H}$ mice, was also only lightly labelled. After 10 days exposure, there were $14.9 \pm 1.8$ grains/cell when A.TH anti A.TL serum was used, and $11.2 \pm 1.4$ grains/cell with A.TL anti A.TH. The differences were not statistically significant. A second experiment gave similar results. Cells from this tumour lack an Fc receptor (N. L. Warner, unpublished data).

\section{Ia antigens on $T$ cell lymphomas}

We have also examined a series of some ten spontaneous lymphomas in A.TH, A.TL and A.SW mice for Ia antigens. All of these tumours have been shown to be positive for Thy 1.2 antigen and negative for surface immunoglobulin by immunofluorescence, and are hence of $T$ cell origin. In every case, the tumours were rejected when transplanted into mice differing at the I region, but only very weak binding was demonstrable with anti Ia serum. Rejection was not due to incompatibility at the TL locus. For example, A.TL tumours were rejected when transplanted into A.TH mice, while they grew rapidly in syngeneic mice. They were also rejected when transplanted into A.TH $\times$ B10.D2 $F_{1}$ hybrids, indicating that the rejection was not due to TL incompatibility (Goding \& Warner, 1975; see discussion section for details of TL differences between A.TH and A.TL mice).

\section{Independent movement of surface immunoglobulin and Ia antigens}

In view of the association between the I region and specific immune response genes, it was of interest to determine the relationship between Ia antigens and $B$ cell surface immunoglobulin. If Ia antigens were immunoglobulin in nature, or were physically associated with immunoglobulin in the membrane, it might be expected that pretreatment of cells with anti immunoglobulin would inhibit the binding of anti Ia serum to B cells and/or that 'capping' of B cell surface immunoglobulin would result in capping of Ia antigens. The results of such an experiment are shown in Table 6. It is clear that there was no significant reduction in the percentage of labelled cells following pretreatment with anti immunoglobulin, and that capping of surface immunoglobulin did not lead to capping of Ia antigens. Similar results

TABLE 6. Independent capping of cell surface immunoglobulin and Ia antigens. Anti Ia serum was used at a concentration of $25 \mu \mathrm{g} / \mathrm{ml}$, and exposure time was 3 days. Cells having more than seven grains were scored as positive

\begin{tabular}{lcc}
\hline Cells & $\begin{array}{c}\text { Labelled } \\
(\%)\end{array}$ & $\begin{array}{c}\text { Capped labelled cells } \\
(\%)\end{array}$ \\
\hline $\begin{array}{l}\text { A.TL spleen cells labelled with FITC anti-immunoglobulin } \\
\text { (sandwich) under capping conditions }\end{array}$ & 45 & 91 (fluorescence) \\
$\begin{array}{l}\text { As above, then cooled to } 4^{\circ} \mathrm{C} \text { and held with }{ }^{125} \text { I A.TH anti A.TL } \\
\text { serum }\end{array}$ & 61 & 2 (radioautography) \\
$\begin{array}{l}\text { A.TL spleen cells held with }{ }^{125} \text { I A.TH anti A.TL serum at } 4^{\circ} \mathrm{C} ; \text { no } \\
\text { prior treatment }\end{array}$ & 60 & 3 (radioautography) \\
$\begin{array}{l}\text { A.TL spleen cells held at } 4^{\circ} \mathrm{C} \text { with }{ }^{125} \text { I A.TH anti A.TL, washed, } \\
\text { held with rabbit anti-mouse Ig under capping conditions }\end{array}$ & 54 & 75 (radioautography) \\
\hline
\end{tabular}


were obtained when the $\mathrm{Fc}$ receptor on B cells was capped prior to treatment with anti Ia serum (J. F. A. P. Miller \& J. W. Goding, unpublished data).

To determine whether Ia antigens on B cells could be capped, spleen cells from A.TL mice were held at $4^{\circ} \mathrm{C}$ for $30 \mathrm{~min}$ with ${ }^{125} \mathrm{I} \mathrm{A.TH}$ anti A.TL washed, and then held with a strong polyvalent rabbit anti mouse IgG serum for $30 \mathrm{~min}$ at $4^{\circ} \mathrm{C}$. The cells were washed again, warmed to $37^{\circ} \mathrm{C}$ for $15 \mathrm{~min}$, and processed for autoradiography. Following this procedure, about three-quarters of the labelled cells were capped as assessed by polar distribution of grains (Table 6).

\section{Characterization of Ia antigens}

In order to characterize Ia antigens, spleen cells from A.TL mice were surface radioiodinated with ${ }^{125} \mathrm{I}$ using the lactoperoxidase technique, lysed with NP-40, and the products precipitated with A.TH anti A.TL serum and analysed by polyacrylamide gel electrophoresis under reducing conditions in the presence of sodium dodecyl sulphate (Fig. 3). A major peak, of molecular weight approximately 30,000 , which migrated just behind the light chain

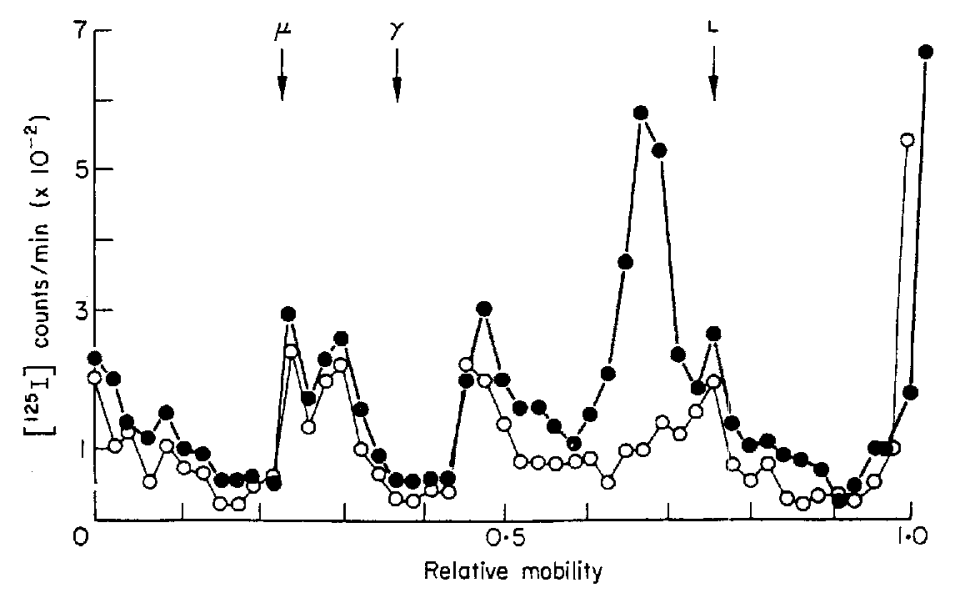

FIG. 3. Analysis by SDS polyacylamide gel electrophoresis of products precipitated from detergent lysates of ${ }^{125}$ I surface labelled A.TL spleen cells by A.TH anti A.TL serum (- $\left.\bullet-\right)$, or normal A.TH serum (-O-O-).

peak, was observed in the experimental (A.TH anti A.TL) group, but not in the control group (normal A.TH serum). Depletion of radiolabelled surface immunoglobulin was not absolute, and small peaks are seen corresponding in mobility to $\mu$ and light chain markers, in both experimental and control gels.

As in other work (Melcher et al., 1974; Hunt \& Marchalonis, 1974; Haustein \& Goding, submitted), two heavy chain peaks were observed. These might differ in carbohydrate (Hunt \& Marchalonis, 1974), or might represent distinct classes of B cell surface immunoglobulin (Melcher et al., 1974). Another minor peak, which migrated slightly ahead of the $\gamma$ chain standard, was also present. This component has been observed elsewhere, and it has been shown to possess an affinity for antigen-antibody complexes (Haustein, Marchalonis \& Harris, 1975). 


\section{DISCUSSION}

Mouse antibodies appear to be particularly susceptible to denaturation by conventional methods of coupling of fluorochromes, 2,4-dinitrophenyl, ferritin, peroxidase and radioiodination by non-enzyme methods (Hämmerling et al., 1974). The results show that lactoperoxidase catalysed ${ }^{125}$ I radio-iodinated anti Ia antisera are a useful tool in the study of Ia antigens.

That the labelling of cells was specific is shown in Fig. 1, which demonstrates that only $2-4 \%$ of A.TH spleen or lymph node cells were significantly labelled by A.TH anti A.TL serum. Thus, significant binding to lymphocytes via $\mathrm{Fc}$ receptors because of aggregates or complexes was ruled out, as was significant labelling due to autoantibodies. Problems due to non complement fixing antibodies, and variations in complement potency and toxicity, which plague cytotoxicity testing, are thus circumvented. However, the technique depends on having antisera of high titre (the A.TH anti A.TL serum used had a titre of 1:2000 by semi-micro cytotoxicity methods), and has so far not proven useful with weaker mouse alloantisera (unpublished data).

The results leave no doubt that the heavily labelled cells were B cells. This is indicated by the organ distribution, effects of anti Thy 1.2 serum, the results of cell population enriched and depleted for B cells, and information from cell electrophoresis. The data are consistent with those of Hämmerling et al. (1974), and Sachs \& Cone (1973). It would appear that rather more cells bind anti Ia serum than bind anti $\mathrm{Ig}$ serum. This was particularly noticeable in the spleen, where a small number of cells (perhaps 5-10\%) bound anti Ia but not anti Ig serum (Fig. 2, Table 6).

Our results also confirm those of Hämmerling et al. (1974), who showed an $84 \%$ reduction in plaque forming cells from $\mathrm{C} 3 \mathrm{H}\left(\mathrm{H}-2^{\mathrm{k}}\right)$ mice treated with A.TH anti A.TL serum and complement. These authors did not specify the dilution of serum used, and only direct (IgM) plaques were studied. Frelinger et al. (1974b) were only able to partially ( $50 \%$ ) inhibit plaque forming cells with anti Ia serum, when using a 1:100 dilution. In view of the very high cytotoxic titre of these antisera against spleen and lymph node cells, these results would suggest that Ia antigens are present in much smaller amounts on plaque forming cells than on other B cells. Such a notion is supported by our finding that an $\mathrm{H}-2^{\mathrm{k}}$ plasma cell tumour (C 1.18) was not significantly labelled with anti la serum.

On the other hand, our results provide strong evidence for the presence of Ia antigens on $T$ cells. This is most clearly indicated in thymus, where rather heterogeneous light but specific labelling was demonstrated (Fig. 1, Table 1). The overall grain counts could not be explained on the basis of B cell contamination, as the labelled cells in the thymus were far more numerous than $B$ cells (approximately $0.5 \%$ of thymocytes bore high density surface immunoglobulin). The labelled cells were much more lightly labelled than B cells.

A.TH and A.TL mice differ at the TL locus as well as at the I region (Frelinger et al,, 1974a). This is the only known antigenic difference outside the H-2 segment. A.TH is $\mathrm{Tla}^{\mathrm{a}}$ $(+1,2,3)$ while A.TL is $\mathrm{Tla}^{\mathrm{c}}(+2)$. These differences arose because the D end of A.TH was derived from $\mathrm{H}-2^{\mathrm{a}}$ while the $\mathrm{D}$ end of A.TL was derived from $\mathrm{H}-2^{\mathrm{d}}$. The $\mathrm{H}-2^{\mathrm{a}}$ chromosome is thought to have arisen by crossing over between $\mathrm{H}-2^{\mathbf{k}}$ and $\mathrm{H}-2^{\mathrm{d}}$, but it is not entirely clear why there should be a Tla difference. A mutation or second crossover early in the development of the $\mathrm{H}-2^{\mathbf{a}}$ chromosome is possible. It is clear that A.TL carries no Tla specificities that are not also carried by A.TH, and thus anti-Tla antibodies would not be expected in this 
direction. Moreover, $\mathrm{Tl}$ antigens are not (as far as is known) expressed on spleen cells, yet the labelling in thymus can be totally abolished by absorption with A.TL spleen cells (unpublished data). It is, therefore, considered that the T-cell binding observed in the thymus was due to anti la antibodies.

The presence of Ia antigens on $\mathrm{T}$ cells is also strongly suggested by the consistent rejection of many different $T$ cell tumours when transplanted into mice which were incompatible at the I region. In at least one instance, such rejection has been shown to be associated with IB or IC region incompatibility (Goding \& Warner, 1975).

The presence of Ia antigens on T cells has also been reported by Götze et al. (1973), but in this publication there was, surprisingly, no evidence for Ia antigens on B cells. Other evidence for Ia antigens on T cells comes from Frelinger et al. (1974b), who were able to show their presence using an extremely sensitive microcytotoxicity test, and Lonai \& McDevitt (1974) who showed that in some situations (especially IC incompatibility) T cells were able to stimulate in the mixed lymphocyte reaction.

The structural genes for mouse immunoglobulin heavy chains (as shown by heavy chain allotypic markers) are not linked to H-2. However, the location in the genome of the genes coding for the $\mathrm{K}$ light chains in the mouse is not known (Cohn, 1972), although in man the InV (light chain) allotypes are not linked to HL-A (Gally \& Edelman, 1972). It was thus possible that the Ia antigens might have represented polymorphisms of $\mathrm{K}$ light chains, which in turn relate to Ir gene effects. However, the demonstration (Table 6) that B cell surface immunoglobulin can be 'capped' without altering the distribution of Ia antigens shows clearly that these surface components consist of different molecules. Our data do not exclude the possibility that a minor subcomponent of Ia antigens is immunoglobulin.

Other strong evidence indicating that the Ia antigens are not immunoglobulin comes from the isolation data. A significant cell surface component precipitable with anti Ia serum is seen on polyacrylamide gel electrophoresis (Fig. 3) following depletion of immunoglobulin. This component has a different mobility on polyacrylamide gel electrophoresis to that of any heavy or light chain described.

It is of interest to note that under strong capping conditions (Table 6) only $75 \%$ of cells bearing Ia antigens could be capped. The inability to cap the remaining $25 \%$ could have at least two reasons. Firstly, if caps are in the axis of the light path, they may not be recognized in smears. Alternatively, it may be that the uncapped cells have a rather low surface density of Ia determinants, preventing their efficient cross-linking.

Analysis of ${ }^{125}$ I cell surface material precipitated by anti Ia serum revealed a single specific peak of molecular weight approximately 30,000 as determined by polyacrylamide gel electrophoresis. This is in general agreement with the results of Cullen et al. (1974), Vitetta et al. (1974) and McDevitt et al. (1974). Our gel patterns show a relatively sharp peak, suggesting limited heterogeneity with regard to overall molecular weight, although the work of Cullen et al. (1974) has shown that at least two antigenically distinct molecules can be precipitated by anti Ia sera in a similar system.

It has been proposed (Dickler \& Sachs, 1974) that the Ia antigens represent polymorphisms of the Fc receptor on B cells. This proposal was based on the finding that anti Ia serum could block binding of aggregates and complexes to the $\mathrm{Fc}$ receptor. We do not favour such an hypothesis, for the following reasons. Firstly, the data presented showed that anti Ia serum directed at either parental I region of $F_{1}$ B cells were potent $(90 \%)$ inhibitors of binding to $\mathrm{Fc}_{\mathrm{c}}$ receptors. These results suggest that the observed blocking was due to steric 
hindrance, since one would expect that if Ia antigens were the Fc receptor, a maximum of $50 \%$ inhibition would be seen for anti Ia directed against either parental antigen of an $F_{1}$ hybrid. Secondly, work has shown that Ia antigens and the $\mathrm{Fc}$ receptor do not co-cap (J. F. A. P. Miller, unpublished data; B. Pernis, personal communication). As for surface immunoglobulin, the possibility that a subclass of Ia antigens might be the Fc receptor has not been entirely excluded. Furthermore, if any of the Ia antigens had the properties of the Fc receptor, they should be precipitable with any immune complex. Recent work(Haustein, Marchalonis \& Harris, 1975) suggests that the radio-iodinated component which migrates slightly faster than the $\gamma$ chain is a possible candidate for the Fc receptor. This component was precipitated by a variety of antigen-antibody complexes.

The functional expression of the H-2 linked $I r$ genes in $\mathrm{T}$ cells suggested that the Ia antigens would also be expressed in T cells. It has been proposed (Benacerraf \& McDevitt, 1972) that the Ir-1 gene codes for the $T$ cell receptor for antigen, a non-immunoglobulin molecule. Our results show clearly that Ia antigens are expressed predominantly on B cells, but the data indicate weaker though unequivocal expression in at least some $T$ cells. The data lend no support to the notion that the Ir-1 gene product is the T cell receptor, but neither do they disprove it. If the $\mathrm{T}$ cell products coded for by this gene were clonally distributed, they might not be detected by our approaches.

There is now considerable evidence against such an hypothesis, however. High and low responder $\mathrm{T}$ cells bind roughly equal amounts of ( $\mathrm{T}, \mathrm{G})-\mathrm{A}-\mathrm{-L}$ (Hämmerling \& McDevitt, $1974 a, b)$ and this binding is inhibitable by antisera directed at both the $\mathrm{K}$ (including I) and $\mathrm{D}$ (not including $\mathrm{I}$ ) region antigens. Anti Ia serum does not inhibit antigen binding by $\mathrm{T}$ cells (Hämmerling \& McDevitt, 1974c). Nabholz et al. (1974) found no inhibition of $T$ cell mediated lympholysis by anti $\mathrm{H}-2$ sera directed against the killer cells.

The inhibition of certain lymphocyte functions, such as antigen induced proliferation, by alloantisera in the guinea-pig is an often quoted argument in support of the receptor hypothesis. However, such inhibition follows the histocompatibility gene status rather than the responder status in animals where these have been separated (Shevach et al., 1974). The inhibition is ineffective when $\mathrm{Fab}_{1}$ fragments of alloantisera are used, even when the reduced avidity of monomeric fragments is taken into account. The inhibition is effective even if the cells are only exposed to the alloantisera several hours after contact with antigen (Bluestein, 1974).

What, then, are the functions of the Ia antigens? How can the Ir gene effects be related to them? At present these questions cannot be firmly answered.

It is clear that the Ia antigens are heterogeneous. At least three I regions and ten Ia specificities have been described (Shreffler \& David, 1974). Future work will have to concentrate on dissecting this heterogeneity, as the antigens controlled by the various regions may have different functions. We propose that the heavy labelling of $B$ cells compared to $T$ cells, and the suggestive evidence of much smaller amounts of Ia antigen on plaque forming cells than on other B cells, indicate that at least one Ia antigen is a differentiation antigen on mature virgin and memory $B$ cells.

An attractive hypothesis is that the $\mathrm{B}$ cell Ia antigens represent a receptor site for the $\mathrm{T}$ cell 'second signal' needed for B cell activation (Katz \& Benacerraf, 1974). The recent demonstration of Ia determinants on 'allogeneic effect factor' (Armerding et al., 1974), the apparent need for I-region identity for T-B collaboration (Katz et al., 1974), and the experiments of Taussig (1974a, b, c) showing an antigen specific $T$ cell collaborative factor 
with $\mathrm{H}$-2 determinants may represent clues to $I r$ gene function. In the latter instance, evidence was presented that $\mathbf{T}$ cells from both responders and non-responders produce the collaborative factor, but only responder $B$ cells are capable of activation by it. Thus, the defect in the non-responders is at the B cell level. On the other hand, this model does not account for the clear demonstration that only responders can mount delayed type hypersensitivity (an exclusive $T$ cell function) against antigens the response to which is under histocompatibilitylinked Ir gene control (Green et al., 1966). Thus, the block in the non-responders could be at any step in the activation of the T cell, but the specificity of the Ir gene effects remains unexplained.

Work is in progress to explore relationships between functional $I r$ genes and the Ia antigens.

\section{ACKNOWLEDGMENTS}

The authors gratefully acknowledge the technical assistance of Ms K. Davern and Ms E. White. We also thank Dr G. F. Mitchell for supplying the thymectomized and reconstituted mice, and Dr M. Vadas for performing thoracic duct cannulations.

Supported by grants from The National Health and Medical Research Council and The Australian Research Grants Committee, Canberra, Australia; by NIH Grants AI-0-3958 and AI-10886, United States Public Health Service and by Contract NO1-CB-23889 with The National Cancer Institute, National Institutes of Health, Department of Health, Education and Welfare, U.S.A.; and by the Volkswagen Foundation Grant No. 112147.

\section{REFERENCES}

ARmerding, D., SACHS, D.H. \& KATZ, D.H. (1974) Activation of $\mathrm{T}$ and B lymphocytes in vitro. III Presence of Ia determinants on allogenic effect factor (AEF). Journal of Experimental Medicine, 140, 1717.

Basten, A., Miller, J.F.A.P., Sprent, J. \& Pye, J. (1972) A receptor for antibody on B lymphocytes. I. Method of detection and functional significance. Journal of Experimental Medicine, 135, 610.

Benacerraf, B. \& MCDeyitT, H.O. (1972) Histocompatibility-linked immune response genes. Science, 175,273 .

BLUESTEIN, H.G. (1974) Alloantiserum-mediated suppression of histocompatibility-linked Ir-gene controlled immune responses. Suppressive effects of IgG fragments derived from alloantisera. Journal of Experimental Medicine, 140, 481.

BoyLe, W. (1968) An extension of the ${ }^{51} \mathrm{Cr}$ release assay for the estimation of mouse cytotoxins. Transplantation, 6, 761 .

Corn, M. (1972) Evaluation and Summary. In: Genetic Control of Immune Responsiveness (Ed. by H.O. McDevitt and M. Landy), p. 367. Academic Press, New York.

Cứllen, S.E., David, C.S., Shreffler, D.C. \& Nathenson, S.G. (1974) Membrane molecules determined by the H-2 associated immune response region: isolation and some properties. Proceedings of the National Academy of Sciences (U.S.A.), 71, 648.

DAvid, C.S., Shreffler, D.C. \& Frelinger, J.A. (1973) New lymphocyte antigen system (Lna) controlled by the Ir region of the mouse H-2 complex. Proceedings of the National Academy of Sciences (U.S.A.), 70, 2509.

DICKLER, H.B. \& SACHS, D.H. (1974) Evidence for identity or close association of the Fc receptor of B lymphocytes and alloantigens determined by the Ir region of the H-2 complex. Journal of Experimental Medicine, 140, 779. 
Frelinger, J.A., MURPHY, D.B. \& MCCORMICK, J.F. (1974a) Tla types of H-2 congenic and recombinant mice. Transplantation, 18, 292.

FRELINGER, J.A., Niederhuber, J.E., DAVID, C.S. \& ShrefFler, D.C. (1974b) Evidence for the expression of Ia ( $\mathrm{H}-2$ associated) antigens on thymus derived lymphocytes. Journal of Experimental Medicine, 140, 1273.

Gally, J.A. \& EDELMAN, G.M. (1972) The genetic control of immunoglobulin synthesis. Annual Review of Genetics, 6, 1.

GoDING, J.W. \& WARNER, N.L. (1975) Transplantation behaviour of A.TH and A.TL T cell lymphomas in congenic resistant and hybrid strains. Submitted for publication.

Gotze, D., Reisfeld, R.A. \& KLEIN, J. (1973) Serological evidence for antigens controlled by the Ir region in mice. Journal of Experimental Medicine, 138, 1003.

GREEN, I., PAUL, W.E. \& BENACERRAF, B. (1966) The behaviour of hapten-poly-L-lysine conjugates as complete antigens in genetic responder and nonresponder guinea pigs. Journal of Experimental Medicine, 123, 859.

Greenwood, F.C., HuNTER, W.M. \& GLOVER, J.S. (1963) The preparation of ${ }^{131}$ I-labelled human growth hormone of high specific activity. Biochemical Journal, 89, 114.

Hämmerling, G.J., Deak, B.D., Mauve, G., Hämmerling, U. \& MCDevitT, H.O. (1974) B lymphocyte alloantigens controlled by the I region of the major histocompatibility complex in mice. Immunogenetics, $1,68$.

HÄMmERLING, G.J. \& MCDevitT, H.O. (1974a) Antigen binding T cells. I. Differences in cellular specificity and influence of metabolic activity on interaction of antigen with $\mathrm{T}$ and $\mathrm{B}$ cells. Journal of Immunology, $112,1726$.

HÄmmERLING, G.J. \& MCDevitr, H.O. (1974b) Antigen binding T and B cells. II. Studies on the inhibition of antigen binding to $\mathrm{T}$ and $\mathrm{B}$ cells by anti-immunoglobulin and anti H-2 sera. Journal of Immunology, $112,1734$.

Hämmercing, G.J. \& MCDevirT, H.O. (1974c) Comparative analysis of antigen-binding T cells in genetic high and low responder mice. Journal of Experimental Medicine, 140, 1180.

HAUPTFELd, V., KLEIN, D . \& KLEIN, J. (1973) Serological identification of an Ir gene product. Science, 181, 167.

Haustein, D., Marchalonis, J.J. \& Harris, A.W. (1975) Immunoglobulin of T lymphoma cells. Biosynthesis, surface presentation and partial characterisation. Biochemistry (in press).

Hunt, S. \& Marchalonis, J.J. (1974) Radioiodinated lymphocyte surface glycoproteins: concanavalin A binding proteins include surface immunoglobulin. Biochemical and Biophysical Research Commumications, 61, 1227.

Katz, D.H. \& Benacerraf, B. (1974) Hypothesis: The function and interrelationships of T cell receptors, Ir genes and other histocompatibility gene products. Transplantation Reviews, 22 (in press).

Katz, D.H., Graves, M., Dorf, M.E., Dimuzio, H. \& Benacerraf, B. (1975) Cell interactions between histoincompatible $\mathrm{T}$ and $\mathrm{B}$ lymphocytes. VII. Cooperative responses between lymphocytes are controlled by genes in the I region of the H-2 complex. Journal of Experimental Medicine, 141, 269.

KINCADE, P.W. \& COOPER, M.D. (1971) Development and distribution of immunoglobulin-containing cells in the chicken. An immunofluorescent analysis using purified antibodies to $\mu, \gamma$ and light chains. Journal of Immunology, 106, 371 .

KUNKEL, H.G. (1954) Zone electrophoresis. In: Methods of Biochemical Analysis, 1, 141.

LAEMMLI, U.K. \& FAVRE, M. (1973) Maturation of the head of bacteriophage T4. I. DNA packaging events. Journal of Molecular Biology, 80, 575.

LoNAI, P. \& McDevirT, H.O. (1974) I-Region genes are expressed on T and B lymphocytes. Journal of Experimental Medicine, 140, 1317.

McDevitT, H.O., Bechtol, K.B., Hämmerling, G.J., LonaI, P. \& Delovitch, T.L. (1974) Ir genes and antigen recognition. In: The Immune System: Genes, Receptors, Signals (Ed. by E.E. Sercarz, A.R. Williamson and C.F. Fox), p. 597. Academic Press, New York.

MARCHALONIS, J.J. (1969) An enzymic method for the trace iodination of immunoglobulins and other proteins. Biochemical Journal, 113, 299.

MARCHALONIS, J.J., CONE, R.E. \& SANTER, V. (1971) Enzymic iodination; a probe for cell surface proteins of normal and neoplastic lymphocytes. Biochemical Journal, 124, 921.

Marchalons, J.J., MoRris, P.J. \& HARRIS, A.W. (1974) Speculations on the function of immune response genes. Journal of Immunogenetics, $1,63$. 
Melcher, U., Vitetta, E.S., McWilliams, M., Lamm, M.E., Phillips-Quagliata, J.M. \& Uhr, J. (1974). Cell surface immunoglobulin. X. Identification of an IgD-like molecule on the surface of murine splenocytes. Journal of Experimental Medicine, 140, 1427.

Nabholz, M., Vives, J., Young, H.M., Meo, T., Miggiano, V., Rijnbieek, A. \& Shreffler, D.C. (1974) Cell mediated cell lysis in vitro: genetic control of killer cell production and target cell specificities in the mouse. European Journal of Immunology, 4, 378.

Nossal, G.J.V., WARner, N.L., LewIs, H. \& Sprent, J. (1972) Quantitative features of a sandwich radiolabelling technique for lymphocyte surface receptors. Journal of Experimental Medicine, 135, 405.

OSmond, D.G. \& Nossal, G.J.V. (1974) Differentiation of lymphocytes in mouse bone marrow. I. Quantitative radioautographic studies of antiglobulin binding by lymphocytes in bone marrow and lymphoid tissues. Cellular Immunology, 13, 117.

Potter, M., FaHey, J.L. \& Pilgrim, H.I. (1957) Abnormal serum protein and bone destruction in transmissible mouse plasma cell neoplasm (multiple myeloma). Proceedings of the Society of Experimental Biology and Medicine, 94, 327.

REIF, A. \& ALLEN, J.M.V. (1963) Specificity of isoantisera against leukaemic and thymic lymphocytes. Nature (London), 200, 1332.

SACHS, D.G. \& CONE, J.L. (1973) A mouse B-cell alloantigen(s) linked to the major histocompatibility complex. Journal of Experimental Medicine, 138, 1289.

SCHLEGEL, R.A. (1974) Antigen-initiated B lymphocyte differentiation. Characterisation of the primary and secondary immune responses of normal and athymic mice to the hapten 4-hydroxy-3-iodo-5 nitrophenylacetic acid (NIP) presented on the carrier polymerised bacterial flagellin (POL). Australian Journal of Experimental Biology and Medical Science, 52, 99.

SheVACH, E.M., Green, I. \& PaUl, W.E. (1974) Alloantiserum-induced inhibition of immune response gene product function. II. Genetic analysis of target antigens. Journal of Experimental Medicine, 139, 679.

Shreffler, D., David, C., Gotze, D., Klein, J., McDevitT, H. \& SACFis, D. (1974) Genetic nomenclature for new lymphocyte antigens controlled by the I region of the H-2 complex. Immunogenetics, 1, 189.

SHREFFLE, D.C. \& DAVID, C.S. (1974) The H-2 major histocompatibility complex and the I immune response region: Genetic variation, function and organisation. Advances in Immunology (in press)

TAussig, M.J. (1974a) T cell factor which can replace T cells in vivo. Nature (London), 248, 234.

Taussig, M.J., Mozes, E. \& IsaC, R. (1974b) Antigen-specific thymus cell factors in the genetic control of the immune response to poly-(tyrosyl, glutamyl)-poly-D,L-alanyl-poly-lysyl. Journal of Experimental Medicine, 140, 301 .

TAUSSIG, M.J. \& MUNRo, A.J. (1974c) Removal of specific co-operative T-cell factor by anti H-2 but not anti Ig sera. Nature (London), 251, 63.

VON BOEHMER, H. (1974) Separation of T and B lymphocytes and their role in the mixed lymphocyte reaction. Journal of Immunology, 112, 70.

voN BoeHmer, H. \& SHORTMAN, K. (1973) The separation of different cell classes from lymphoid organs. IX. A simple and rapid method for removal of damaged cells from lyrnphoid cell suspensions. Journal of Immunological Methods, 2, 293.

ViTETTA, E.S., KLEIN, J. \& UHR, J.W. (1974) Partial characterization of Ia antigens from murine lymphoid cells. Immunogenetics, 1, 82. 